\title{
5
}

\section{Paul de Man and the Triumph of Falling}

Deconstruction seeks a reversal of values, conferring a new kind of meaning on those elements of literature that critics have traditionally ignored. Whereas literary criticism has most often focused on similarities, unities, coherence, systematic ideas, and the body of the work, deconstruction draws attention to contradictions, obscurities, discontinuities, interruptions, margins, and plays of the signifier. It approaches the work of literature by reinscribing its major term within its minor one, by resetting its margins, and by subverting hierarchical and systematic elements. Deconstruction can be said to have marginalized the reading of literature.

This emphasis on the marginal, however, takes on moral overtones in its opposition to relations of power and systematic thought. Deconstructive marginalization has the ethical virtue of siding with the underdog in the system; it upsets traditional systems of power by exposing to what extent minor and marginal elements define their relations. Deconstruction acts to combat all forms of theory because it equates systematic thought with the violence of power. Paradoxically, however, this crusade grants great power to the enterprise of deconstruction, and the theory risks the same kinds of aggressions and exclusions 
that it associates with other systems. Some deconstructive critics have dealt with this paradox by embracing a type of philosophical martyrdom, in which they expose the violence of power, but do not partake of it, by sacrificing themselves to its fury. The martyr triumphs at the moment of falling, but does not commit the sin of enjoying the victory. What happens to this moral triumph, however, when martyrdom assumes the form of a theory, when it acquires the magnitude of a movement, when martyrdom becomes systematic?

Writing of the implicit system underlying the practice of deconstruction, Barbara Johnson strikes upon the phrase "rigorous unreliability" to characterize the methods of Paul de Man. ${ }^{1}$ As a critical summation, it is both rigorous and reliable. The extent to which the term "rigorous unreliability" complies with deconstructive marginalization emerges when one considers alternative phrases. Johnson might have chosen "unreliable rigor," but what would that phrase have meant? "Unreliable rigor" would be an apt label for traditional literary theory as de Man sees it. Such theory strives for coherence and unity, but its striving, de Man has argued, is unreliable because of the very rigor of its attempts. Such theory depends on the power of a system that remains inherent, but that decides the conception of what is literary a priori. These theories risk violating their objects, de Man writes, for they rely on "systematic nonunderstanding and misrepresentation" ("The Resistance to Theory" 12). They are, in fact, mere "theory," if we follow de Man's definition: "by theory one understands the rooting of literary exegesis and of critical evaluation in a system of some conceptual generality" ("The Resistance to Theory" 5).

Theorizing, for de Man, falls prey to the will to system. It

1. Barbara Johnson, "Rigorous Unreliability," Critical Inquiry 11.2 (1984): 27885 . Frequently cited references will be given parenthetically. They include Paul de Man, Blindness and Insight (1971; reprint, Minneapolis: University of Minnesota Press, 1983), The Rhetoric of Romanticism (New York: Columbia University Press, 1984), "The Resistance to Theory," Yale French Studies 63 (1982): 3-20, Introduction to The Selected Poetry of Keats, ed. de Man (New York: New American Library, 1966), and Sigmund Freud, The Standard Edition, ed. James Strachey, 24 vols. (London: Hogarth, 1953-74). References to the poetry of Keats and Shelley make use of de Man's citations. 
cannot escape the violence of either appropriating all diversity to its system, of imposing itself as a system, or defining its systematic nature on the exclusion of "inappropriate" elements. Consequently, de Man tries to distance himself from more traditional critics by redefining theory as an antitheoretical stance. Opposed to the theory of others, his theory at least tries to upset "rooted ideologies by revealing the mechanics of their workings; it goes against a powerful philosophical tradition of which aesthetics is a prominent part; it upsets the established canon of literary works and blurs the borderlines between literary and non-literary discourse. By implication, it may also reveal the links between ideologies and philosophy" ("The Resistance to Theory" 11-12).

De Man's ethics consists largely in his opposition to systematic thought; yet he remains systematic in his preference for moral unreliability and resistance. That he believes his position to be irrefutable further complicates matters, for the claim to irrefutability risks deploying an aggressive force far exceeding the intensity and violence of his critical opponents, who do not pretend to infallibility. De Man addresses the problem of his troublesome irrefutability in a confessional mode in "The Resistance to Theory," referring to the "correct" rhetorical method of reading associated with him: "Technically correct rhetorical readings may be boring, monotonous, predictable and unpleasant, but they are irrefutable. They are also totalizing (and potentially totalitarian) for since the structures and functions they expose do not lead to the knowledge of an entity (such as language) but are an unreliable process of knowledge . . . they are indeed universals, consistently defective models of language's impossibility to be a model language" (20).

What bothers de Man about his theory is its rigor and potential for ideology, totalization, and, most important, totalitarianism. De Man sees himself becoming a systematic thinker whose stern interpretation of the law risks dangerous generality. Indeed, he describes his views as a "universal theory of the impossibility of theory" (20). Generality is the hallmark of the kind of theory that de Man most opposes, and yet his own work has become irrefutable. De Man concludes "The Resistance to 
Theory" by lamenting the permanence of theoretical systems: "Nothing can overcome the resistance to theory since theory is itself this resistance. The loftier the aims and the better the methods of literary theory, the less possible it becomes. Yet literary theory is not in danger of going under; it cannot help but flourish, and the more it is resisted, the more it flourishes, since the language it speaks is the language of self-resistance. What remains impossible to decide is whether this flourishing is a triumph or a fall" (20).

De Man's conclusion raises many questions. Why does he take recourse to the opposition between triumph and fall, when his theory works determinedly to scramble such polarities? What has theory become? Is his theory a triumph over other theories, or does his triumph mean that he has fallen? If he has fallen, does it represent in his eyes some kind of triumph?2 $\mathrm{My}$ reading of de Man will comment on the foregoing passage, the complexity of which resounds through his entire corpus. It will lead through de Man's writings on Freud, Keats, and Shelley.

\section{Resistances}

The knowledgeable reader may start at the mention of de Man's writings on Freud. There are, in fact, no essays on Freud in de Man's published works, and the absence is curious given the status of Freud in modern critical theory. Richard Klein has noted that de Man manages to write on Binswanger, a leading figure in the history of psychoanalysis, without mentioning Freud. ${ }^{3}$ Yet de Man's work echoes with the ideas of psychoanalysis, even though he has expressly attributed his awakening to the complexities of blindness and insight to his readings of Heidegger and not of Freud. ${ }^{4}$ Klein locates the scene of Freud's

2. Cf. Jacques Derrida's bon mot "Whoever loses wins," in Margins of Philosophy, trans. Alan Bass (Chicago: At the University Press, 1982), p. 21.

3. Richard Klein, "The Blindness of Hyperboles: The Ellipses of Insight," Diacritics 3.2 (1973): 33-44, esp. 38.

4. Robert Moynihan, "Interview with Paul de Man," Yale Review 73.4 (1984): 576-602. Here de Man notes that Heidegger plays the role for him that Freud plays for Derrida in the deconstructive enterprise. 
influence on de Man in "The Rhetoric of Blindness," but the closest encounter may occur in the essay "The Resistance to Theory" because the title invites a comparison with Freud's "The Resistances to Psycho-Analysis" (1925), written at the request of Albert Cohen for La Revue Juive.

At first glance the two essays on resistance seem worlds apart. Freud insists that the resistance to psychoanalysis depends on its sexual content, the narcissistic injury to the self in the wake of discovering its subordination to powerful unconscious forces, and ultimately to the fact of Freud's Judaism. De Man asserts that theory is resisted simply because it is a language about language. Freud's remarks, however, include a definition of the unconscious that has some impact on de Man's theories. Freud attacks the classical opposition between what is mental and what is unconscious, affirming that a philosopher will find the psychoanalytic principle that "what is mental is in itself unconscious" a contradiction in terms and will thus "fail to observe that in making this judgement he is merely repeating his own definition of what is mental" (19:216). Freud is criticizing the philosopher whose system interferes with observation, whose a priori suppositions determine conclusions. Similarly, Freud can attack the religious mind, the system of all systems, in Civilization and Its Discontents by exposing that "no one, needless to say, who shares a delusion ever recognizes it as such" (21:81).

To demystify metaphysical suppositions, one exposes the conceptions that support them, their unconscious, so to speak. But when Freud transforms the unconscious from a state of mind into a system, he disposes of the very opposition between what is mental and what is unconscious upon which such demystifications rest. Once the opposition between knowing and unknowing disappears, concepts such as "theory," "ideology," and "mythology" cannot be sharply divided. Indeed, when the unconscious becomes a system, expelling ideology and mythology risks their return in another form. A given theory may seem to expose the workings of an unconscious mythology or ideology, but the consciousness of theory cannot be maintained apart from the unconscious movements of its objects, for any theory capable of uncovering unconscious move- 
ments must supposedly be an expression of them. In effect, the philosophical implications of Freud's theory of the unconscious destroy the hopeful and constructive nature of his clinical designs. The analyst can never know more than the patient and, moreover, risks trading places with the patient at any moment. Unconscious error returns as the essence of conscious thinking.

As Freud was fond of explaining, the unconscious cannot say no, and no one can say no to the unconscious. Anyone who confronts the unconscious falls under its power, for strong opposition, especially, signals that one has already succumbed to its influence. Freud's theories certainly opened a new chapter in the rhetoric of persuasion. He discovered a nearly invincible rhetorical argument for the superiority of his views. But the basis of Freud's power is not merely rhetorical; it is ethical. Freud realized in a theoretical reversal of awesome proportions the negative image of absolute community toward which ethics has always strived. The unconscious possesses the organizing capacity and inclusiveness toward which all ethical systems reach, but it does not define its "community" on the basis of exclusions. The discovery of the unconscious is of enormous advantage to those who believe that antisystematic thought is ethically superior to the order of systems, for it gives them the impression of assaulting their antagonists systematically without partaking of the violence of a system. One might say that Freud discovered not the unconscious, but the possibility of the systematically unsystematic, for the unconscious in Freud's view remains the system to end all systems. ${ }^{5}$

The triumph of psychoanalysis, however, relies on its ability to be systematic and irrefutable, and here the parallels to de Man's essay grow most apparent. It is always possible, Freud

5. It may seem outlandish to argue that Freud was against systematic thought. I do not mean that Freud is a champion of delirium, as certain thinkers wish to see him. Freud is frequently most opposed to systematic thought when it is someone else's system, although to a great extent what is most admirable about Freud is his willingness to remain open to exploration, to contradict himself rather than risk missing a new perception. The dislike of systematic thought, for instance, defines his greatest criticism of Adler: "The Adlerian theory was from the very beginning a 'system' - which psycho-analysis was careful to avoid becoming" (14:52). 
assures the reader, to convince the opponents of analysis in precisely the same way as one convinces individual neurotics under treatment. "The position," he confesses, "was at once alarming and consoling: alarming because it was no small thing to have the whole human race as one's patient, and consoling because after all everything was taking place as the hypotheses of psycho-analysis declared that it was bound to" (19:221). No matter how troublesome it is to be the world's confessor, Freud enjoys his infallibility. The resistance to psychoanalysis proves the truth of his theories; it is part of the theory.

De Man's rhetoric follows Freud's example. The resistance to theory is interior to theory itself, "since theory is itself this resistance" (20). The conclusion is self-resistant, for de Man's theory represents what everyone else resists, placing him in the "selfdestroying" position that he associates with Romantic writers. It is also self-promoting, naturally, for de Man's definition of theory describes his own views. By identifying himself as the most rigorous proponent of theory's self-resistance, de Man creates the unique position that distinguishes him as a critic, and here de Man's essay truly merges with Freud's. Although "The Resistance to Theory" contains no sign of the overt reference to self apparent in Freud's advocacy of Judaism, de Man shares Freud's willful isolation. Freud claims that the resistance to psychoanalysis derives from his opponents' distaste for Jews, but he makes that same distaste a condition for the discovery of his theories: "Nor is it perhaps entirely a matter of chance that the first advocate of psycho-analysis was a Jew. To profess belief in this new theory called for a certain degree of readiness to accept a situation of solitary opposition-a situation with which no one is more familiar than a Jew" (19:222). Analogously, de Man's essay on resistance begins by stating how his personal theories have been resisted by the MLA, but ends by defining that same resistance as the essence of critical theory.

Accepting the marginal position, paradoxically, does not mean that either de Man or Freud will remain on the margins, outside the boundaries of the system; it is rather the first step in a triumph that will marginalize the system. But the triumph becomes a fall, if one is as antisystematic as de Man, because it 
also systematizes the marginal. The only possible value to be given to martyrdom consists in its refusal on ethical grounds to stand for the aggressive and exclusionary impulses of some forms of systematic thought. Once martyrdom becomes a theory, however, it fails to direct its aggression neither toward its enemies nor toward itself. It becomes a system bent on its own destruction as the first step in destroying the violence that it associates with others. Its motivations are ethical, but ethically misguided because it trades a less sure form of violence for one that strives to encompass everything. Nihilism in the modern world may be defined as the preference for nothingness over the risk of committing an act of violence. Since nihilists cannot escape the equation within the philosophical tradition between violence and negativity, however, they must accuse themselves of violence as well. General and particular, system and fragment, inside and outside merge, as one makes an example of oneself, and in the same way as one's enemies do. Such is the perverse logic called self-martyrdom.

\section{Hyperion's Fall}

Nowhere in de Man is there a fall as stern and reliable as Keats's fall. In the early Introduction to the New American Library edition of Keats's poetry (1966), de Man argues that the necessity of Keats's death is the negative moment that completes his consciousness of self. For the great Romantics, de Man insists, "consciousness of self was the first and necessary step toward moral judgment" (xxxiv). Such statements sound odd in the context of the late de Man, for whom self-consciousness is impossible and moral judgment, as traditionally defined, an infernal proposition. But the early de Man has not yet traded the search for either self-consciousness or moral choice for an ethics based on linguistic pluralism. Indeed, the Introduction argues that Keats risks losing his status as one of the great Romantic poets because his hatred of self does not permit the consciousness necessary to a complete ethics. Consequently, de Man's explicit task is to establish Keats's evolution from a disinterested sympathy toward human suffering to a sympathy 
based on a more mature identification between the suffering of humanity and his own suffering. To arrive at this identification, de Man submits, Keats must accept his own death without succumbing to the thrill of victorious martyrdom.

Romanticism identifies with the martyrs, the marginals, and the victims of history. It asserts the role of nature in an encompassing culture, the role of the fragmentary in the system, and sides with the outside over the inside; as a result, one can see why the ethics of Rousseau and Romanticism exerts such an influence on modern thought, including in this regard deconstruction. ${ }^{6}$ The marginalization of the system is clearly an

6. The deconstructive theories of both de Man and Derrida continue the reversal of values inherent in the Romantic project. In both thinkers, however, the marginality of their positions also threatens the ethical impulses of Romanticism and its claims to knowledge. Here their respective readings of Rousseau are illuminating. De Man's interpretation is clearly the most extreme. De Man conceives of no position superior to Rousseau's own insights, whereas Derrida allows that Rousseau may be demystified (even though the task is ultimately an exercise in futility on Derrida's part). De Man's "The Rhetoric of Blindness" refuses to take Rousseau as an object by positing a definition of literature in which the literary takes itself as its own object: he calls "literary" in the full sense "any text that implicitly or explicitly signifies its own rhetorical mode and prefigures its own misunderstanding as the correlative of its rhetorical nature, that is, of its 'rhetoricity' " (136). In short, de Man underbids Derrida in the process of deconstructive marginalization. Rousseau's text deconstructs itself, de Man argues, and Derrida's reading is flawed simply because it takes an object other than itself.

De Man thus transforms into an irrefutable necessity of interpretation the conspiracy against Rousseau of which Derrida's reading is a continuation. What critics call Rousseau's paranoia becomes an inevitable fact of reading, not only of Rousseau but of all subjects. The necessity of this misinterpretation consists in de Man's assertion that "interpretation is nothing but the possibility of error" (141). To avoid the accusation of superiority and maintain his marginal position, de Man identifies himself with Rousseau. Like Rousseau, for example, he discovers the model for language in the "self-destructiveness of music." At the same time, he establishes as the universal property of all writing, including his own, the wounding self-reflexivity of Rousseau's language. For de Man, Rousseau represents the exemplary case of the "self-indictment" on which Western philosophy is founded, and de Man follows Rousseau's example by identifying this self-indictment with language itself. De Man becomes Rousseau to be himself. De Man and all writers are trapped within the position called "Rousseau."

Such self-reflexivity, however, has nothing to do with the reflections of knowledge. Indeed, neither Derrida nor de Man allows that self-reflexivity may be other than a property of blindness. Here Rodolphe Gasché, in an otherwise valuable essay, misses the point in his comparison of Derrida and de Man. He 
ethical gesture on the part of Romantic poets, but the identification with the marginal threatens to create a perverse form of self-martyrdom, in which the writer plays the role of poète maudit. In this case, the Romantic's sympathy toward those who suffer becomes in Nietzsche's words a "mendacious form of egoism." Yet it would be a mistake not to stress the ethical impulses apparent in the gestures of even the most zealous victims of the Romantic agony. The figure of the poète maudit conceals, as the essence of its ethical character, a genuine sensitivity to human suffering, violence, and death.

Keats preserves a similar sensitivity to suffering, but does not fall into the lure of mendacious egoism. His great ethical achievement remains a reluctance to see himself as a martyr for literature, despite his ineluctable mortality and thie power that he bestows upon the poet. Not surprisingly, the early de Man praises Keats for managing to avoid the narcissistic extremes of the poète maudit: "it is one of Keats's most engaging traits that he resists all temptation to see himself as the hero of a tragic adventure" (Introduction xi). Whether Keats's attitude came from his personal experience of mortality can only be surmised, but it is surely less exciting to pretend to be in the grasp of death, when death holds one firmly, and Keats's fatal illness may well have made him less enthusastic about the poetics of suffering embraced so zealously by his Romantic contemporaries.

Most often, however, de Man has mistakenly played out the Romantic preoccupation with suffering in terms of the poet's struggle against time and impermanence. This preoccupation with time appears in de Man's early reading of Keats and re-

argues that de Man's emphasis on self-reflexivity is an effect of turning deconstruction into literary criticism, whereas Derrida's views simultaneously assert and undo self-reflexivity. There is only the slightest degree of difference, however, between Derrida's assertion that self-reflexivity disrupts itself and de Man's idea that self-reflexivity is its own blindness. The difference is merely one of accent. But it is important because the strong emphasis that de Man gives to self-reflexivity permits one to focus clearly on the severity of deconstruction's self-resistance. De Man's claim that literary language always blinds itself is especially self-destructive. Literature, like Oedipus, is always on the verge of suicide. See Rodolphe Gasché, "Deconstruction as Criticism," Glyph 6 (1979): 177-215. 
mains throughout his writings, most notably in "The Rhetoric of Temporality." The theme of time opens the way to the ethical orientation of Romanticism, but continues to obscure it in the symbolism of time and nature. Repeatedly, de Man seems to take the perspective of the "Cold Pastoral," striving toward a language dispossessed of human subjectivity. The sylvan historian of "Ode on a Grecian Urn," for example, possesses beauty only because it seems to remain untouched by human misery and the chaotic scenes that it portrays: "Cold Pastoral! / When old age shall this generation waste, / Thou shalt remain, in midst of other woe. . . ." From the perspective of the urn's cold serenity, images of human woe carry no emotional or subjective content. Its surfaces display human loss, but from the urn's point of view nothing is missing, because it does not understand human suffering in the first place and its images remain intact and in time.

Similarly, de Man's theories of language perpetuate an abstract portrayal of time and nature. Human subjectivity for de Man is an illusion of language, and violence relates ultimately to the tendency of language to advance from meaning to meaning without grounding itself. De Man's theories take the modern doctrine of the arbitrariness of language to its most extreme expression, where meaning can only be intentionless, and death and love are linguistic predicaments and not human experiences. ${ }^{7}$

Only when the idea of human suffering sheds its abstract association with time and assumes a more concrete representation of human loss does Keats's ethics make sense. The idea of history, not merely of time, is necessary to give the ethical elements of love and sympathy their relation to human suffering.

7. In "Autobiography as De-Facement," The Rhetoric of Romanticism (67-82), de Man describes death as a "linguistic predicament" (81). And, in his last lecture, he interprets the suffering of the translator as a statement on the "specifically linguistic" nature of suffering in general (38). See "'Conclusions' on Walter Benjamin's 'The Task of the Translator,'" Yale French Studies 69 (1985): 25-46. Finally, de Man's early review of Harold Bloom's The Anxiety of Influence, collected in Blindness and Insight (267-76), polemically asserts that linguistic structure is the cause of subjective affects and that influence is a linguistic not a psychological property. 
The early de Man understands that "the power by means of which the poet can redeem the suffering of mankind is called love" (xvii). Moreover, he stresses that love in Keats must not be linked with pure sensation, as the early detractors of Keats's love poems to Fanny Brawne argue. Sympathy is more important than sensation because it counterbalances the Romantic tendency toward excessive egotism and its mirror image, excessive selflessness. But the danger of love for Keats remains its "self-destroying" power because its sacrifices may lead to the egotism of self-martyrdom:

But there are

Richer entanglements, enthrallments far More self-destroying, leading, by degrees, To the chief intensity: the crown of these Is made of love and friendship, and sits high Upon the forehead of humanity.

(Endymion 1.797-802)

Although Keats intends the self-destroying power of love to establish moral disinterestedness, the early de Man shows precisely to what extent self-destruction can be wholly interested. Keats's desire for communion threatens to overwhelm his sense of self, and de Man concludes that "negative capability" begins to serve not as a means of extending sympathy but as a tactic designed to escape self-reflection. Keats's self-repugnance potentially marginalizes him, removing him from the sphere of his own ethical sympathies. His ethical system remains incomplete as long as it does not include the self. Keats moves, de Man summarizes, "away from the burden of self-knowledge into a world created by the combined powers of the sympathetic imagination, poetry and history, a world that is ethically impeccable, but from which the self is excluded" (xxiv).

De Man's analysis of negative capability is striking, but it introduces a temporal warp in his own understanding: his early description of the potential dangers of negative capability applies to his late theory of deconstruction. Deconstruction, as de Man practices it, also strives for an ethically impeccable world, but it excludes the self. Deconstruction considers the self as both 
a great mythology and the source of aggressive impulses; yet, as de Man's early analyses conclude, expelling the self for ethical reasons leads to a mendacious form of egoism and a voracious paradox. First, it martyrs the self to give it greater luminosity and power. Second, it leads to an ethics that may seem impeccable but that achieves its faultless nature not by solving problems but by disavowing them. A moral philosophy that does not include the self may seem faultless, but its perfection rests in reality on the enormous void left by its rejection of the human. Removing the human from ethics leaves it without a basis for existence, since ethics is by definition profoundly anthropocentric.

If Keats's ethical sympathies are to survive, he must overcome the temptation to martyrdom that his hatred of self conceals. He must also overcome the temptation to see the poet as the savior of humankind. The Fall of Hyperion brings the historical consciousness necessary to the task. It is not about eternity, like the "Ode on a Grecian Urn," but about those who fall in history. The poem exposes the sacrificial nature of history, but it extends sympathy to its victims. Unlike Hyperion, it sees no new god of poetry arise from the conflict. Nor does the poet muster the resurrection of the fallen. Rather, the poet, overwrought by his own mortality, presides as the witness of the fruits of violence:

A long awful time

I looked upon them; still they were the same;

The frozen God still bending to the Earth,

And the sad Goddess weeping at his feet.

Moneta silent. Without stay or prop

But my own weak mortality, I bore

The load of this eternal quietude,

The unchanging gloom. . . .

(The Fall of Hyperion 1.384-91)

The passage is notable because it represents not the triumph of the Olympians but the fall of the Titans. The poem sympathizes with the sacrificed of history, and Keats's accent on the poet's frozen mortality creates a parallel between the situations of the Titans and the poet, prefiguring the identification necessary to bring the self back into Keats's ethically impeccable world. 
The Titans' fall defines the sacrificial character of history. Without it there would be no insight. Similarly, Keats's fall is necessary to prompt the self-knowledge necessary to complete his ethics. De Man locates the final scene of Keats's self-consciousness in "This Living Hand":

This living hand, now warm and capable

Of earnest grasping, would, if it were cold

And in the icy silence of the tomb,

So haunt thy days and chill thy dreaming nights

That thou wouldst wish thine own heart dry of blood

So in my veins red life might stream again,

And thou be conscience-calmed-see here it is-

I hold it towards you.

The hands clasp in a waltz of life. The image of the lifeless hand of the poet, introduced by the conditional "if," stirs the reader's desire to bring the poet back to life even at the cost of death. But the poet will not permit it and comes back from his nightmarish death to prevent the sacrifice and to join the living in love and friendship. As de Man remarks, the poet no longer saves humanity. He takes the position of the victim; and yet Keats does not succumb to the temptation of self-destruction. ${ }^{8}$ He neither sacrifices himself for the reader by refusing to return from the world of "if" to the world of the living, nor does he simply relish death, but instead demonstrates in the offer of the final line the desire to live. The love of sympathy leads to life and puts an end to the "self-destroying" love of Endymion.

"This Living Hand" destroys the barriers created by modern criticism between the general and particular, between the system and fragment, and between the saved and the martyred. It

8. Elsewhere de Man makes a similar inference. Writing of Hölderlin and Keats, he insists that "what first appears as an act of intellectual growth and insight gradually takes on an ethical dimension of supreme sacrifice, of suicide in the highest possible sense. Both poets become increasingly aware of this as their meditation progresses, and their works shift from the theme of historical rejuvenation to sacrifice." Nevertheless, as de Man concludes of the poet in The Fall of Hyperion, "the actual sacrifice is not within his power; and the poet is merely the one who has seen the sacrifice, with the mind's eye, as Moneta reveals it to him." See "Keats and Hölderlin," Comparative Literature 8 (1956): 4344 . 
refuses to end with the marginalization or self-martyrdom of poets by asserting their severe isolation from humanity. To the contrary, the poem is a moment of strict binding that excludes no one. De Man rightly associates the poem with the greatest achievement of Romanticism: "Romantic literature, at its highest moments, encompasses the greatest degree of generality in an experience that never loses contact with the individual self in which it originates" (xxxiv). Romantic literature at its best strikes outward toward the ethical gesture of inclusion with the knowledge of the dangers of generality and particularity, of the twofold temptations of exclusive system and excluded martyrdom, and this scope of understanding makes possible what de Man calls "philosophical generality rooted in genuine self-insight" (xxxiv). It also makes possible Keats's late "philosophical" acceptance of the powers that force self-knowledge.

\section{Hyperion Falling}

Hyperion cannot be made an example or make an example of himself if he does not fall. If Hyperion continues to fall, if he is always already falling, there is no exclusive system and no excluded martyrdom. But there is also no insight, no "philosophy" in Keats's sense, except for the insight that one is falling, "falling back to nought," de Man remarks in his Preface to The Rhetoric of Romanticism.

In "The Resistance to Theory," de Man abandons his ethical reading of Keats's poetry. That Keats was unable to complete either Hyperion or The Fall of Hyperion, de Man concludes, "manifests the impossibility, for him as for us, of reading his own title" (16). Keats's death has nothing to do with it. Nor does Keats ever risk achieving the self-knowledge necessary to mature ethical judgment. Rather, de Man's rereading of Keats serves as an example of why resistance to theory thrives. Such resistance is a "resistance to the rhetorical or tropological dimension of language." Resistance no longer expresses subjective emotions, as it did in Freud, but merely indicates the workings of positional language; and language definitively usurps the position of the self. Indeed, the "self" in de Man is the position in language than cannot comprehend language. 
No longer the product of Keats's ethical struggles, The Fall of Hyperion now appears as a classic example of language's resistance to language. The genitive in the title frustrates grammatical readings, de Man argues, for it could mean either "Hyperion's Fall," the story of a definitive defeat, or "Hyperion Falling," the story of an incessant falling, in which Apollo, Hyperion, Keats, and the reader are all interchangeable and constantly plunging downward. De Man also reads The Fall of $\mathrm{Hy}$ perion intertextually as a gloss on Keats's earlier Hyperion. The late poem tells the story of the failure of the first poem. Yet the fall of Hyperion does not signify the triumph of The Fall of Hyperion because both poems remain unfinished. De Man asks whether the title does or does not tell "the story of why all texts, as texts, can always be said to be falling" (17). The rhetoric of the poem suggests opposing grammatical readings, necessarily making the title unreadable. And the poem's unreadability parallels a crisis of understanding in which the author and reader share. "Just as Keats had to break off his narrative," de Man contends, "the reader has to break off his understanding at the very moment when he is most directly engaged and summoned by the text" (17). Nor does de Man permit a sympathy between poet and reader, of the kind found in "This Living Hand," to exist within the realm of possibility: "One could hardly expect to find solace in this 'fearful symmetry' between the author's and the reader's plight since, at this point, the symmetry is no longer a formal but an actual trap, and the question no longer 'merely' theoretical" (17).

Keats's ethically impeccable system needs only to include the self to reach perfection. When the self enters the system, the system unites the particular and the general with an ethical gesture, but de Man now associates all generalized systems with the impulse toward totalization and totalitarianism. Just as The Fall of Hyperion is for de Man the story of the failure of Hyperion, "The Resistance to Theory" becomes the story of the failure of de Man's early reading of Keats. The Fall of Hyperion risks letting the self arrive, and de Man's rhetorical reading deliberately suspends Hyperion in midair. De Man's sense of "Hyperion Falling" indefinitely postpones the arrival of the self. He freezes Keats's progress toward greater self-consciousness at an earlier 
stage, before he learns to fall and to accept his own death. Consequently, de Man also remains at an early stage.

De Man's insistence on the state of falling serves to defer the fall necessary to punctuate any system. Yet the idea of a system need not be violent, unless one believes that institutions can never escape their origins. Rather, the historical tendency of systems to create exclusions is violent. The essentially ethical impulse not to exclude therefore begins by targeting systematic thought as the worse offense. But ethics does not consist merely in this impulse. In point of definition, ethics is a system that denies those systems defined by their exclusions, and it works ideally toward an inclusive community of human beings. De Man's love of paradox remains an ethical response to the perceived violence of systematic thought, but he goes awry when he expels the idea of system as necessarily violent while constructing his own marginal system. In the end, his refusal to confront the self as well as his systematic exclusion of the self from the literary work risk, as did Keats's "self-destroying" love, the temptation of self-martyrdom and the glorification of the self through its failures. At this point, rigor mortis sets in and threatens de Man with its irrefutable necessity.

\section{The Triumph of Disfigurement}

"Shelley Disfigured" revolves around the same problems as "The Resistance to Theory" and the Introduction to Keats's poetry. De Man concludes "that The Triumph of Life is a fragment of something whole, or romanticism a fragment, or a moment, in a process that now includes us within its horizon" (94). As in the early essay on Keats, de Man defines Romanticism as a movement whose formulations encompass its potential criticism and redefinition. The self-resisting power of Romanticism also parallels that of theory and literary language. Romanticism begins to take shape as the most "literary" and "theoretical" movement.

Although the theories of Romanticism argued in the essays on Shelley and Keats are strikingly consistent in some ways, the meaning of The Triumph of Life differs radically from Keats's poetry, as de Man had previously described it. Unlike Keats's 
"This Living Hand," Shelley's poem follows a trajectory of disfigurement, in which the loss of the eyes means the loss of insight. "This trajectory from erased self-knowledge to disfiguration," de Man summarizes, "is the trajectory of The Triumph of Life" (100). De Man's reading of Shelley disposes of every idea that had meaning for him in Keats as well as any idea that might associate Romanticism with higher ethical ideals. He insists that traditional interpretations of the poem, which seem to rely on a discarded passage where Rousseau admonishes the poet not to repeat the mistakes of his generation, cannot be supported. The interpretation "is a clear example of the recuperation of a failing energy by means of increased awareness," and when de Man discards it, he discards in effect his old reading of Keats (96). The sense of communion between poet and reader found in "This Living Hand" falters without the possibility of an identifying sympathy between them. And all sense of reciprocity between the poet and the fallen is erased. Rather, de Man bases his interpretation on Shelley's isolation of Rousseau from the other representatives of the Enlightenment. Rousseau's encounter with the "shape all light" becomes a scene dramatizing "the failure to satisfy a desire for self-knowledge" (99). Rousseau is not a "spoiler spoiled," who warns the poet not to play the role of spoiler. Instead, Rousseau laments, "I was overcome / By my own heart alone," and adopts the pose of the martyr (102).

Rousseau's insight is his blindness, his self-resistance, and his inability to attain self-knowledge. Like the other symbols of achievement, Aristotle and Plato, Rousseau becomes in de Man's reading a double figure, whose fall and triumph merge. In this sense, The Triumph of Life also acquires a double meaning in de Man's estimation. He identifies life with an eroding process, and once more, the theory of blindness and insight calls forth the ideas of psychoanalysis. The words of Freud, "the aim of all life is death" (18:38), intervene as if to pervert the victory of life, and The Triumph of Life becomes the triumph of death. My allusion to Freud makes sense in the contexts of de Man's theory of blindness and insight and of Romanticism. If Romanticism is the movement that prefigures and incorporates its own crit- 
icisms, the movement that cannot be transcended, it takes on the form of a historicized and all-inclusive unconscious system.

Civilization and Its Discontents seems to confirm the inference that de Man's view of Romanticism owes a debt to Freud. The same elements are in play and hold similar positions in their arguments. Like de Man, Freud pits the forces of love and death against each other. The book begins by reducing Romain Rolland's "oceanic feeling" of sympathy to narcissism, as de Man does in the case of Keats, and moves to attack other Romantic conceptions. Chapter 3 reads as a sustained critique of the Romantic notions that civilization is largely responsible for human misery, that the "noble savage" actually possesses a simpler life than others, and that science does not mean genuine benefits and advances. And yet for all of the criticisms of Romanticism, Freud seems unable to transcend the movement. Civilization and Its Discontents remains a fundamentally Romantic work. Indeed, its title has become the apotheosis of the Rousseauistic separation between nature and culture.

Most important, Civilization and Its Discontents exposes the logical link between the Keats and Shelley of de Man. The book insists on the brutal and random force of death, as does de Man's reading of Shelley. It pits the forces of necessity against those of love, as does de Man's reading of Keats. Keats's greatest temptation in de Man's eyes remains similar to the forces that destroy Rousseau in Shelley. Keats risks being overcome by his own heart alone and failing to achieve the self-knowledge necessary to his mature ethics. The key to Keats's victory rests in his ability to translate his own suffering, without succumbing to a sense of glorious martyrdom, into an identifying and conscious sympathy toward human suffering in general. The selfdestroying dimension of love must be surpassed and aggression disengaged from love. Freud tells precisely the same story about civilization, and his first attempt at a conclusion duplicates Keats's findings:

The fateful question for the human species seems to me to be whether and to what extent their cultural development will succeed in mastering the disturbance of their communal life by the 
human instinct of aggression and self-destruction. . . . Men have gained control over the forces of nature to such an extent that with their help they would have no difficulty in exterminating one another to the last man. They know this, and hence comes a large part of their current unrest, their unhappiness and their mood of anxiety. And now it is to be expected that the other of the two "Heavenly Powers," eternal Eros, will make an effort to assert himself in the struggle with his equally immortal adversary. (21:145)

The antidote to the self-destroying power of humankind consists of knowledge and "eternal Eros." Freud ends with Keats's solution. But it was not Freud's final word. When the menace of Hitler became apparent to him in 1931, he appended a final sentence: "But who can foresee with what success and with what result?" The statement inserts a moment of doubt concerning the triumph of Eros and departs from Keats's "philosophy." But the phrase also returns Freud to the conclusion of "The Resistances to Psycho-Analysis." Hitler takes the shape of the death drive in Freud's mind and poses a special threat to the Jewish advocate of psychoanalysis. Hitler symbolizes the conditions of isolation necessary to Freud's theories as well as the dreaded inevitability of humanity's martyrdom at its own hands.

De Man's reading of Shelley follows the same itinerary, pursuing the insight of self-martyrdom. First, it disposes of the idea that Rousseau might present knowledge to the poet. In a series of Freudian passages, de Man gives privilege to the process of forgetting over that of consciousness. Since the repressed must always return, Shelley's poet is condemned to repeat Rousseau's aberrations in a more violent mode (just as de Man is condemned to repeat Rousseau more violently in "The Rhetoric of Blindness"). Consequently, de Man believes, "The Triumph of Life can be said to reduce all of Shelley's previous works to nought" (120). Second, de Man takes exception to Donald Reiman's suggestion that the "shape all light" might represent Julie as a figure of love. The rejection of Reiman's reading is also a rejection of the mature love associated in the early Introduction with Keats's moral philosophy. Instead, the "shape all light" 
metamorphoses into a Narcissus figure, just as Rolland's "oceanic feeling" derives from narcissism. Furthermore, the "shape all light" in its narcissistic function exposes the self-reflexive nature of Shelley's poem and of all literature. "We now understand," de Man insists, "the shape to be the figure for the figurality of all signification" (116). The Triumph of Life becomes definitively the fall of life and the triumph of death, for what the figure of figurality reveals is the repressive and violent nature of language. The waning of the light-shape results, de Man holds, from "a single, and therefore violent, act of power achieved by the positional power of language considered by and in itself" (116).

Literary language illuminates the violence of language, although not in a manner that guarantees a knowledge of violence or of language itself. The insight is rather, in de Man's theory, the emergence of pure violence and power. Language is itself the manifestation of violence acting on violence, of fire consuming fire, of light making the perception of light impossible. Metaphor is as violent as the deadly Apollo, "for the initial violence of position can only be half erased, since the erasure is accomplished by a device of language that never ceases to partake of the very violence against which it is directed. It seems to extend the instantaneousness of the act of positing over a series of transformations ..." (118-19). Apollo metamorphoses into Lucifer, and the figure of Satan against himself sinks "'below the watery floor' trampled to death by its own power" (119). Just as Freud's Todestrieb seems to ensure mankind's self-destruction, dreadful necessity arises in the form of language's "self-resisting" power. Language creates the conditions for our self-martyrdom. Its power corrupts absolutely, and Shelley's poem becomes de Man's morality play. Its moral reveals that knowledge and power destroy themselves and their possessors. Consequently, The Triumph of Life translates triumph into fall; it insists on the impassable distance between an actual victory, a "triumph," and the trionfo, "the pageant that celebrates the outcome of battle" (116). The triumph never arrives, as de Man's Hyperion never hits bottom; rather, the triumph remains a thriambos, an eternal hymn to the danse macabre and to the Dionysian destruction that is life. 
The death of Shelley assures the triumph of death and casts an ironic pall over the poem's title. Shelley's defaced body appears in the margins of the poem in de Man's interpretation. His sole task is to textualize it. The task is easy because the abruptness and arbitrariness of Shelley's death imitate the random events portrayed in the poem. The arbitrariness of death and of language become one: "The Triumph of Life warns us that nothing, whether deed, word, thought, or text, ever happens in relation, positive or negative, to anything that precedes, follows, or exists elsewhere, but only as a random event whose power, like the power of death, is due to the randomness of its occurrence" (122). In the case of Keats, the power of death completes a system. It allows Keats to make more impeccable his ethical world. In the case of Shelley, the power of death ensures the fragmentation of the system, for de Man argues that its arbitrary and brutal arrival makes The Triumph of Life an impossible subject and a more impossible poem.

"Shelley Disfigured," however, does end systematically. First, it creates a unity between Shelley's disfigurement and de Man's theories and ends by embracing a strange form of self-marginalization. Shelley's fate becomes merely a trope in the linguistic predicament called death, and de Man cites it as a theoretical justification of his view that language and death are one. Second, "Shelley Disfigured" contains a deliberation on the problems of theory, anticipating de Man's final words in "The Resistance to Theory." In both essays, de Man contrasts those theories that ground themselves in natural relations with his own theory of rhetoric and its insistence on arbitrariness. But he cannot separate the two and refers to both with the same kinds of images: the belief in the natural grounding of meaning "functions along monotonously predictable lines, by the historicization and the aesthetification of texts, as well as by their use, as in this essay, for the assertion of methodological claims made all the more pious by their denial of piety" (122). As in the essay on the resistance to theory, de Man and his detractors achieve unity in a negative moment. His piety defines theirs by exposing the inevitability of piety.

De Man's piety is the piety of Shelley disfigured. It is the piety of martyrdom dependent upon the marginalization of systems. 
"Shelley Disfigured" insists that falling and triumphing are the same process, and it aligns itself with the inevitability of fragmentation-in the form of Shelley's body, his poem, and the movement of Romanticism itself-thus promoting its own marginalization. The final lines of the essay assert the marginal values of deconstruction by writing the last lines of "The Resistance to Theory" not in the language of triumph and fall, but in a language opposed to generality and systematic thought: "Reading as disfiguration, to the very extent that it resists historicism, turns out to be historically more reliable than the products of historical archeology. To monumentalize this observation into a method of reading would be to regress from the rigor exhibited by Shelley which is exemplary precisely because it refuses to be generalized into a system" (123).

The lines are also a rewriting of de Man's early essay on Keats. There he defined Romanticism and Keats's place among the great Romantic poets in terms of their ability to encompass "the greatest degree of generality in an experience that never loses contact with the individual self in which it originates" (xxxiv). ${ }^{9}$ Now that generality, which characterizes the highest moment of Romanticism, has been killed by necessity. Philosophical generality is the death of genuine self-knowledge, and history portrays nothing but the ineluctable necessity of fragmentation and the triumph of death and disfiguration. In its wake, triumph and fall, criticism and literature, insight and blindness cannot be opposed.

9. A final image associated with the procession of figures in The Triumph of Life poses an alternative to de Man's interpretation. I cite from Shelley's Poetry and Prose, ed. Donald H. Reiman and Sharon B. Powers (New York: Norton, 1977):

"These shadows, numerous as the dead leaves blown

"In Autumn evening from a popular tree-

Each, like himself and like each other were,

At first, but soon distorted, seemed to be. . . ."

(528-31)

The lines expose a merging between the general and particular similar to the identifying sympathy found in Keats's "This Living Hand" and associated with the highest achievement of Romanticism. 


\section{Falling to Nought}

Rhetoric may transform Hyperion's fall into a falling or postpone for a time the brutal and definitive triumph of life. But rhetoric remains rhetoric and knows nothing of love and death.

The Preface to The Rhetoric of Romanticism was written in the shadow of death, and it carries the signs of de Man's unfortunate and premature passing. Unlike Keats's late poetry, however, the essay does not move beyond the Romantic rhetoric of suffering toward a theory of human sympathy based on an identification between individual and general suffering. De Man seems unable, unlike the Keats of his early Introduction, to transform the knowledge of his own death into an ethical moment and still resist the thrill of martyrdom. Rather, the Preface is an exercise in rhetoric, and it makes a final statement on the martyred language of de Man's deconstructive theories.

The prefatory essay elaborates precisely those rhetorical theories, found in de Man's late writings on Keats and Shelley, that make impossible an identifying sympathy between the dying person and the rest of humanity. It enshrines the marginal values of deconstruction as well as de Man's personal failings. The only unity possible, the "false unity" of the book, is the responsibility of another: de Man insists that the essays were collected at the initiative of the editor of the Columbia University Press. No system or coherence may be found between its covers, and the associations between the essays are as random as those of the figures passing in Shelley's The Triumph of Life. "The fragmentary aspect of the whole," de Man admits about the book, "is made more obvious still by the hypotactic manner that prevails in each of the essays taken in isolation, by the continued attempt, however ironized, to present a closed and linear argument. This apparent coherence within each essay is rot matched by a corresponding coherence between them. Laid out diachronically in a roughly chronological sequence, they do not evolve in a manner that easily allows for dialectical progression or, ultimately, for historical totalization" (viii). The movement away from totalization and generality apparent in earlier essays animates the passage, and indeed de Man is stirred by his own 
inability to comment on what he has done. Each essay seems to begin "from scratch," and their conclusions "fail to add up to anything" (viii). He finds himself unable to articulate "some secret principle of summation" (viii).

De Man's sense of his difference from other theorists again tries to assert itself, but it succeeds to a degree not achieved in the other essays. As such, the Preface becomes de Man's definitive statement on his own martyrdom to the system that he has created. Instead of portraying himself as being sacrificed equally with others to the "self-resisting power" of language, he stands alone in the insight of his blindness. In no way does the Preface appropriate those who resist theory to the workings of theory. Rather, it describes them as optimistic thinkers to be envied and suspected and from whom de Man feels essentially estranged: "One feels at times envious of those who can continue to do literary history as if nothing had happened in the sphere of theory, but one cannot help but feel somewhat suspicious of their optimism" (ix). The negative unity stressed by "The Resistance to Theory" is simply impossible, and de Man stamps the book with the imprint of failure: "The Rhetoric of Romanticism should at least help to document some of the difficulties it fails to resolve" (ix). In effect, the book's title is true to the principle that it expresses, for de Man's theory confides increasingly as it develops that the rhetoric of Romanticism reveals insight only into its own failures.

Finally, de Man makes a last attempt to achieve a unity between the level of his style and that of history. His style has been to state "the inevitability of fragmentation in a mode that is itself fragmented" (ix). And he attains unity with the ideals of Romanticism as he has described them. He aspires to the discursive elegance of those Romantic writers who teach the insight of the figurality of all signification, and like those writers, he seems to think it "a small price to pay, perhaps, compared to the burden of constantly falling back to nought" (ix). Just as The Triumph of Life in de Man's reading negates Shelley's previous writings, the Preface reduces all of de Man's "previous work to nought." Indeed, de Man concludes by mentioning "Shelley Disfigured" 
as his best effort at facing questions about history and fragmentation. There death is portrayed as the totalizing god of language, and we are sacrificed in its name. ${ }^{10}$

Death is, in effect, the perfect antisystem, more perfert by far than the Freudian unconscious. Its flawless negativity consumes our parodic and addled attempts to mimic its perfection in life. For de Man, the violence of philosophical generality is arbitrary and common compared to the dreadful necessity of death. Death casts its shroud on all equally and with cruel justice. It permits no escape and no insight, but it holds a special torture for those who cling in the knowledge of their blindness to the delights of martyrdom. Death defines their being, and it can be neither arbitrary nor tame. The only knowledge valued by the martyr is the inexorable fatality of blindness, for it defines the possibility of martyrdom and gives one brief insight into the triumph of falling.*

10. Only its penultimate sentence suggests another mood. This line states de Man's characteristic vision of blindness and insight, but hints that the future of criticism-and perhaps his future-"is far from clear, but certainly no longer simply a matter of syntax and diction" (ix). Whether de Man is referring to a necessity beyond grammatical and rhetorical readings is a question that those acquainted with him personally might know better than I how to answer. It remains, however, that de Man was unable in his writings to move beyond the experience of death. Elsewhere I have argued that de Man's work elaborates a rhetoric of mourning that requires the idea of death, and not absence, to create its coherence. See "Paul de Man and the Rhetoric of Selfhood," New Orleans Review 13.1 (1986): 5-9.

*Author's note to 1990 printing: The texts of Paul de Man's wartime journalism were discovered after The Ethics of Criticism had gone to press. For an analysis of de Man's journalistic writings that builds upon the remarks here, see my "Mourning Becomes Paul de Man," in Werner Hamacher, Neil Hertz, and Thomas Keenan, eds., Responses: On Paul de Man's Wartime Journalism (Lincoln: University of Nebraska Press, 1989), pp. 363-67. 